\title{
PROCEEDINGS OF THE EIGTH INTERNATIONAL CONFERENCE ON RHETORIC AND SCRIPTURE
}

\section{Preface}

$\mathrm{T}$

his volume consists of selected and approved Proceedings from the $8^{\text {th }}$ International

Conference on Rhetoric and Scriptures. It continues a proud tradition which originated in 1992 in Heidelberg, Germany. Tom Olbricht explains that in 1990 it occurred to me that while Americans interested in rhetorical analysis met with some frequency, non international conferences of rhetorical specialists had convened. Eventually with the support of Wuellner and Hester, the decision was made to hold the conference at Pepperdine University's Moore Haus in Heidelberg in July of $1992^{\prime 1}$ (Porter and Olbricht 1993, 9). The second conference took place in South Africa in 1994 and was, at least from a South African perspective, a huge success. Ten years later and the tradition still continues. Small scale, expertise enterprises do not always survive for a long period in the academic world. We owe it to the commitment of people such as Tom Olbricht, Jim Hester, Vernon Robbins and Wilhelm Wuellner that this tradition continued. Not only is the publication of these papers a tribute to these scholars, not only do the contributors want to commemorate the performance of Wilhelm Wuellner - who made an immense contribution to disclose the world of Rhetoric to those interested in the academic study of religion - and not only do we want to continue this tradition, but we also hope to present a publication that would do this tradition proud and would also effect an appropriate continuation.

South African bodies are political bodies. A physiology as innocent and as inevitable as skin colour has been infused with a politicality dividing the population of this country, empowering some to act with an attitude, and disfranchising others to have neither attitude nor self-respect. With a different type of democracy emerging in 1994, South Africans were for the first time introduced or confronted with the notion of human rights. And yes, we have hoped that with a Constitution which ranks in the league of the most prominent democracies in the world, that the dawn of 'equality' will also dismiss difference. That did not happen, and we know now, that it will not happen and neither do we desire it to happen, because we have learnt not only to live with difference but also to appreciate difference, not only to accommodate or tolerate but to celebrate difference. And yet, our democracy is very fragile, and our Constitution is no magic wand dispelling racism, gender inequalities, ageism and, low and behold, forms of reversed Apartheid. A politics of the body which has been formed for three centuries in South Africa and even for a much longer time outside our borders, still determines our interaction and religious discourses still perpetuate a politics of the body which enhances and promotes discrimination.

Since both body politics and religious discourses are constituted by rhetorical practices, rhetoric may help us in understanding the mechanisms that structured them, whether that be in the realm of early Christianity or in Japanese religions. To help us, not only to understand, not only to subvert and expose, but also to create a body politics appropriate to our time and spaces, this volume is published under the theme: The Rhetoric(s) of Body Politics and Religious Discourses.

As will be seen in the introductory article as well as in the arrangement of articles it was indeed possible to identify certain types of rhetoric. However, although it was possible to

1. Olbricht, T 1993. Preface. Pages 9-10 in Rhetoric and the New Testament: Essays from the 1992 Heidelberg Conference. Edited by SE Porter and TH Olbricht. Sheffield: Sheffield Academic Press. 
find some kind of structure no claim is made on its precise demarcation and overlap abounds. The authors were also neither restricted to a particular approach, nor a particular rhetoric or any specific topic. The introductory article provides with the context in which the Conference was held and explains why a particular arrangement of articles has been followed. In conformity with Scriptura's open policy concerning referencing and format, a liberal approach was followed and each author was given leeway to work within a style of convenience.

A Conference, such as the one we held in Pretoria during August 2004, and the consequent publication of the papers in this volume, are events that owe their existence to the sheer passion, gusto, dedication, enthusiasm and innovation of several people. A word of thanks is an insufficient gesture, but nonetheless a token of sincere appreciation and this should go to the following people: Professor H L Bosman (Stellenbosch University), as our 'contact-editor' from Scriptura who has gone more than the required two miles in having this volume published, and who has exhibited extreme patience and cooperation; the reviewers of the articles, who have often on short notice assisted in evaluating and making suggestions; the National Research Foundation, who has partially sponsored our guest lecturers in cooperation with Unisa and the the University of Johannesburg (previously RAU); Unisa's emerging Research Section for their willingness in financially assisting the publication of this volume as an edition of Scriptura, containing all the selected contributions in one volume. A special word of thanks to Ms Lizel Voges-Bonthuys, who was responsible for editing most of the nitty-gritty of each article and who was at all times willing and prepared to yet again scrutinise these articles. Her contribution, however, would not have been possible were it not for the funding of her temporary assistance, received from the Research Institute for Theology and Religious Studies at Unisa.

On behalf of the contributors to this volume, I hope that the potential which rhetorical enquiry has for the Humanities will emerge and that you, as reader, will share in the democratic and intellectual joy which this field of study has given us.

- Johannes N (Vossie) Vorster 